\title{
The Relationship between Economic Growth and Electricity Consumption in Sri Lanka
}

\author{
K. K. C. S. Kiriella, W. L. T. Peiris, W. H. A. Samarakoon, K. T. A. B. Samarasinghe, W. D. A. S. \\ Wijayapala, and M. P. Dias
}

\begin{abstract}
This paper applies to Sri Lanka an econometric model named as Vector Error Correction Model (VECM) and simple econometric model developed by H.Y. Yang (2000) which can be used for testing the presence of the relationship between economic growth and electricity consumption in Sri Lanka for the period of 1985-2015. The results obtained from the research can be used to justify the investments in electricity sector because of the significant contribution it makes to the economy and the macro economic planning. The research has been separated into four scenarios in order to check the impact to the economic growth from different sectors (Total electricity consumption and total real GDP, Industrial sector electricity consumption and industrial Sector real GDP, Commercial sector electricity consumption and service sector real GDP, [Industrial + Commercial] sector electricity consumption and [Industrial + Service] sector real GDP). The economic output generated from [Industrial + Commercial] sector has a strong relationship with [Industrial + Service] sector electricity consumption. Also, the results obtained suggests that the past and the current electricity consumptions have a significant impact to the economic growth in Sri Lanka.
\end{abstract}

Index Terms-Economic growth, electricity consumption, simple econometric model, Sri Lanka, vector error correction model.

\section{INTRODUCTION}

Electrical energy plays a major role in the modern society. It is a crucial factor for both developing and developed countries. Electricity consumption leads to the productivity and industrial growth and it directly affects to the economic growth.

The relationship between economic growth and electricity consumption of a country depends on the condition of the economy of a country and the structure of it. The causal relationship between these two factors can be categorized into three factors: no causality, uni-directional causality and bi-directional causality. Also, it can be categorized as longterm causality and short-term causality.

In the Sri Lankan context, the electric utilities are operated as vertically integrated monopoly system. All utilities from electricity generation to electricity sales are managed by the government. Due to this direct ownership of the government all investments that needs for the electricity

Manuscript received December 14, 2019; revised March 8, 2020

K. K. C. S Kiriella, W. H. A Samarakoon, and K. T. A. B Samarasinghe were with the University of Moratuwa, Sri Lanka; are now with private sector, Sri Lanka (e-mail: chandikasudul@gmail.com, warunahasun@gmail.com).

W. L. T. Peiris is with Government University, Sri Lanka (e-mail: lemashap@tech.sab.ac.lk).

M. P. Dias was with University of Moratuwa, Sri Lanka.

W. D. A. S Wijayapala is with University of Moratuwa, Sri Lanka. sector are done by the government, prices are set by the government and all the revenue goes to the government.

This paper reviews the relationship and the impact of electricity consumption on the economic growth. The results of this research demonstrates that the investments in electricity sector are fully justified. Also, the direction of causality helps the policy makers to get appropriate decisions and results can be used for macroeconomic planning.

\section{REVIEW OF LITERATURE}

Most of the researches in this area address the causality between electricity consumption and economic growth and marginal values to economic output. R. Morimoto and C. Hope studied the impact of electricity supply on economic growth in Sri Lanka from 1960 to 1998 by using the model developed by H.Y Yang (2000) who found the bi-directional causal relationship in Taiwan for the period of $1954-1997$. Morimoto et al. said that the current and past changes in Electricity supply have a significant impact to the economic growth in Sri Lanka. Also they predicted that for every 1 MWh increase in Electricity supply there is an extra economic output between the ranges of 88000 to 137000 [1].

Another research carried out by Zahid Asghar named as "Energy GDP Relationship: A causal analysis for five countries of South Asia" investigated causal relationship between GDP and Energy Consumption for five South Asian Countries; Pakistan, India, Sri Lanka, Bangladesh and Nepal by using Toda and Yamamoto (1995) approach and Error correction model. He found that Electricity Consumption and GDP are co integrated and there is long run relationship uni-directional causality from GDP to Electricity Consumption. Then he denotes that Sri Lanka has less energy dependent economy energy conservation policies have opposite effects. He said further in his study "As economic growth causes expansion in industrial and commercial activities and electricity is used as a basic input, therefore, energy conservation policies do not harm the economic growth [2]."

In the year of 1998 Sharmin and Mohammed conducted a research for Sri Lanka by applying Johansen's cointegration tests. They found that using trivariate Vector Error Correction Model (VECM) energy consumption to economic growth in Sri Lanka. They used energy consumption, income and price levels and presented that energy consumption is relatively exogenous and it directly influence to the income and prices [3].

The summary of other literature review on Electricity Consumption and Economic growth is presented in the 
Table I and Table II below.

TABLE I: FOR DEVELOPING COUNTRIES

\begin{tabular}{|c|c|c|c|}
\hline Study & $\begin{array}{l}\text { Country } \\
\text { (Period) }\end{array}$ & Method & Findings \\
\hline $\begin{array}{l}\text { Gurgul and } \\
\text { Lach } \\
\text { (2011) }[4]\end{array}$ & $\begin{array}{l}\text { Poland } \\
(2000- \\
2009)\end{array}$ & $\begin{array}{c}\text { Linear and } \\
\text { Nonlinear } \\
\text { Causality Tests }\end{array}$ & $\begin{array}{c}\text { Bidirectional } \\
\text { Causality between } \\
\text { GDP AND Economic } \\
\text { Growth }\end{array}$ \\
\hline $\begin{array}{c}\text { Ghosh } \\
\text { (2002) [5] }\end{array}$ & $\begin{array}{c}\text { India } \\
(1950- \\
1997)\end{array}$ & $\begin{array}{l}\text { Granger } \\
\text { Causality }\end{array}$ & $\begin{array}{c}\text { Bidirectional } \\
\text { causality between } \\
\text { Economic growth and } \\
\text { Electricity } \\
\text { Consumption }\end{array}$ \\
\hline $\begin{array}{c}\text { Jumbe } \\
(\mathbf{2 0 0 4 )}[6]\end{array}$ & $\begin{array}{c}\text { Malawi } \\
(1970- \\
1999)\end{array}$ & $\begin{array}{c}\text { Granger } \\
\text { Causality, error } \\
\text { correction } \\
\text { model }\end{array}$ & $\begin{array}{c}\text { Bidirectional } \\
\text { causality between } \\
\text { Economic growth and } \\
\text { Electricity } \\
\text { Consumption }\end{array}$ \\
\hline $\begin{array}{c}\text { Adom } \\
\text { (2011) [7] }\end{array}$ & $\begin{array}{l}\text { Ghana } \\
(1971- \\
2008)\end{array}$ & $\begin{array}{c}\text { Toda and } \\
\text { Yamamoto } \\
\text { Granger } \\
\text { Causality Test }\end{array}$ & $\begin{array}{l}\text { Unidirectional } \\
\text { causality from } \\
\text { Economic growth to } \\
\text { Electricity } \\
\text { Consumption }\end{array}$ \\
\hline $\begin{array}{l}\text { Atif and } \\
\text { Siddiqi } \\
(2010)[7]\end{array}$ & $\begin{array}{l}\text { Pakistan } \\
(1971- \\
2007)\end{array}$ & $\begin{array}{c}\text { Granger } \\
\text { Causality Test } \\
\text { and Modified } \\
\text { WALD Test }\end{array}$ & $\begin{array}{l}\text { Unidirectional } \\
\text { causality from } \\
\text { Electricity } \\
\text { Consumption to } \\
\text { Economic Growth }\end{array}$ \\
\hline $\begin{array}{l}\text { Aktas and } \\
\text { Yilmaz } \\
(\mathbf{2 0 0 8 )}[8]\end{array}$ & $\begin{array}{l}\text { Turkey } \\
(1970- \\
2004)\end{array}$ & $\begin{array}{l}\text { Granger } \\
\text { Causality }\end{array}$ & $\begin{array}{l}\text { Unidirectional } \\
\text { causality from } \\
\text { Economic growth to } \\
\text { Electricity } \\
\text { Consumption }\end{array}$ \\
\hline $\begin{array}{l}\text { Mozumder } \\
\text { and } \\
\text { Marathe } \\
\text { (2007) [9] }\end{array}$ & $\begin{array}{c}\text { Bangladesh } \\
(1971- \\
1999)\end{array}$ & $\begin{array}{l}\text { Co-integration, } \\
\text { vector error } \\
\text { correction } \\
\text { model }\end{array}$ & $\begin{array}{l}\text { Unidirectional } \\
\text { causality from } \\
\text { Economic growth to } \\
\text { Electricity } \\
\text { Consumption }\end{array}$ \\
\hline
\end{tabular}

TABLE II: DEVELOPED COUNTRIES

\begin{tabular}{|c|c|c|c|}
\hline Study & $\begin{array}{c}\text { Country } \\
\text { (Period) }\end{array}$ & Method & Findings \\
\hline $\begin{array}{c}\text { Shiu and } \\
\text { Lam } \\
(\mathbf{2 0 0 4 )}[10]\end{array}$ & $\begin{array}{c}\text { China } \\
(1971- \\
2000)\end{array}$ & $\begin{array}{c}\text { Error Correction } \\
\text { model }\end{array}$ & $\begin{array}{c}\text { Unidirectional } \\
\text { Causality from } \\
\text { Electricity } \\
\text { Consumption to } \\
\text { Economic Growth }\end{array}$ \\
\hline $\begin{array}{c}\text { Yang } \\
(\mathbf{2 0 0 0 )}[11]\end{array}$ & $\begin{array}{c}\text { Taiwan } \\
(1954- \\
1997)\end{array}$ & Granger Causality & $\begin{array}{c}\text { Bidirectional causality } \\
\text { between Economic } \\
\text { growth and Electricity } \\
\text { Consumption }\end{array}$ \\
\hline $\begin{array}{c}\text { Yoo (2005) } \\
{[12]}\end{array}$ & $\begin{array}{c}\text { Korea } \\
(1970-\end{array}$ & $\begin{array}{c}\text { Error Correction } \\
\text { model }\end{array}$ & $\begin{array}{c}\text { Bidirectional causality } \\
\text { between Economic } \\
\text { growth and Electricity } \\
\text { Consumption }\end{array}$ \\
\hline $\begin{array}{c}\text { Yoo (2006) } \\
{[11]}\end{array}$ & $\begin{array}{c}\text { Malaysia, } \\
\text { Singapore }\end{array}$ & $\begin{array}{c}\text { Granger } \\
\text { Causality, } \\
\text { Hsiao's } \\
\text { Version of } \\
\text { Granger Causality }\end{array}$ & $\begin{array}{c}\text { Bidirectional causality } \\
\text { between Economic } \\
\text { growth and Electricity } \\
\text { Consumption }\end{array}$ \\
\hline $\begin{array}{c}\text { Cheng } \\
(\mathbf{1 9 9 5 )}[13]\end{array}$ & $\begin{array}{c}\text { US (1947- } \\
\text { Cointegration, } \\
\text { Granger Causality }\end{array}$ & No causality \\
\hline
\end{tabular}

\section{METHODOLOGY}

The study was conducted using time series analysis for the period of 1985 to 2015. Reliable data for electricity consumption and GDP were obtained from Ceylon Electricity Board (CEB) and Central Bank Sri Lanka (CBSL) respectively. Analysis was carried out for four scenarios to check the significant impact of the electricity consumption on the economic growth in Sri Lanka. Analyzed four scenarios are;

- Total Electricity consumption and Total real GDP

- Industrial Sector Electricity Consumption and Industrial Sector real GDP

- Commercial sector electricity consumption and Service sector real GDP

- (Industrial + commercial) sector electricity consumption and (Industrial + service) sector real GDP.

Base year for all the cases has been taken as 2015 . Several econometric models have been analyzed for the Sri Lankan context such as Auto Regressive (AR), Moving Average (MA), Auto Regressive Moving Average (ARMA), Auto Regressive Integrated Moving Average (ARIMA), Auto Regressive Distributed Lag (ARDL), Vector Auto Regressive (VAR), and Vector Error Correction Model (VECM). Finally VECM is selected among the other econometric models to perform the time series analysis for the Sri Lankan data. Raw data should not be stationary and all the data should be integrated in same order to use the Vector Error Correction Model (VECM). It can be described as follows:

$$
\begin{array}{r}
\Delta G D P_{t}=C_{1}\left(G D P_{t-1}+\alpha \times E L E C T_{t-1}+\beta\right)+ \\
\sum_{i=1}^{n} a_{i} \times \Delta G D P_{t-i}+\sum_{j=1}^{n} b_{j} \times \Delta E L E C T_{t-j}+E_{t}
\end{array}
$$

where;

$$
\Delta \mathrm{GDP}_{t}=\text { First differenced real GDP at time } t
$$

$\Delta \mathrm{ELECT}_{t-i}=$ First differenced electricity consumption at time $t-i$

$$
\begin{gathered}
E_{t}=\text { Error term } \\
C_{1}, \alpha, \beta, a_{i} \text {, and } b_{j}=\text { constants }
\end{gathered}
$$

\section{A. Total Electricity Consumption and Total Real GDP}

Augmented Dickey-Fuller (ADF) test was used to check the stationarity of the $\triangle \mathrm{GDP}$ and $\triangle \mathrm{ELECT}$. Data collection should be stationary to overcome the occurrence of spurious regression. Both data collections are significant at 5\% level and the obtained results are shown in the Table III and Table IV respectively.

TABLE III: STATIONARY TEST RESULTS FOR $\Delta$ GDP

\begin{tabular}{|c|c|c|c|}
\hline \multicolumn{2}{|c|}{} & $\mathrm{t}$ - Statistic & Probability \\
\hline \multirow{2}{*}{$\begin{array}{c}\text { Augmented Dicky - Fuller Test } \\
\text { Statistic }\end{array}$} & -5.010881 & 0.0019 \\
\hline \multirow{2}{*}{$\begin{array}{c}\text { Test Critical } \\
\text { Values: }\end{array}$} & $1 \%$ Level & -4.309824 & \\
\cline { 2 - 4 } & 5\% Level & -3.574244 & \\
\cline { 2 - 4 } & 10\% Level & -3.221728 & \\
\hline
\end{tabular}

TABLE IV: STATIONARY TEST RESULTS FOR $\triangle$ ELECT

\begin{tabular}{|c|c|c|c|}
\hline \multicolumn{2}{|c|}{$\begin{array}{c}\text { Augmented Dicky - Fuller Test } \\
\text { Statistic }\end{array}$} & -6.937821 & 0.0000 \\
\hline \multirow{2}{*}{$\begin{array}{c}\text { Test Critical } \\
\text { Values: }\end{array}$} & $1 \%$ Level & -4.339330 & \\
\cline { 2 - 4 } & $5 \%$ Level & -3.587527 & \\
\cline { 2 - 4 } & $10 \%$ Level & -3.229230 & \\
\hline
\end{tabular}

Johanson cointegration test has been performed afterwards. Johanson cointegration test is used to check whether there is long run relationship between real GDP and electricity consumption. It is also significant at 5\% level. Results of the Johanson cointegration test for total electricity consumption and total real GDP are illustrated in Table V. 
Statistics show that there is a long run relationship between $\triangle \mathrm{GDP}$ and $\triangle \mathrm{ELECT}$.

TABLE V: RESULTS OF JOHANSON COINTEGRATION TEST

\begin{tabular}{|c|c|c|c|c|}
\hline $\begin{array}{c}\text { Hypothesized } \\
\text { No. of CE(s) }\end{array}$ & $\begin{array}{c}\text { Eigen } \\
\text { value }\end{array}$ & $\begin{array}{c}\text { Trace } \\
\text { Statistic }\end{array}$ & $\begin{array}{c}0.05 \\
\text { Critical } \\
\text { Value }\end{array}$ & $\begin{array}{c}\text { Probability } \\
* *\end{array}$ \\
\hline None $*$ & 0.548329 & 32.52327 & 15.49471 & 0.0001 \\
\hline At most * & 0.336193 & 11.06362 & 3.841466 & 0.0009 \\
\hline Trace test indicates 2 cointegrating eqn(s) at the 0.05 level \\
\hline *denotes rejection of the hypothesis at the 0.05 level \\
\hline **Mackinnon-Haug-Michelis (1999) $\mathrm{p}-$ values \\
\hline
\end{tabular}

After performing the ADF test and Johanson cointegration test, optimum time lag for the econometric model was obtained using Akaike information criterion (AIC). Obtained value is illustrated in Table VI and it is 27.66. According to the results, optimum time lag for total electricity consumption and total GDP became 5 years.

TABLE VI: ECONOMETRIC MODEL FOR THE 1ST SCENARIO $\mathrm{D}(\mathrm{GDP})=\mathrm{C}(1) *(\mathrm{GDP}(-1)-738.17482962 * \operatorname{ELEC}(-1)-$ $628583.194996)+\mathrm{C}(2) * \mathrm{D}(\mathrm{GDP}(-1))+\mathrm{C}(3) * \mathrm{D}(\mathrm{GDP}(-2))+\mathrm{C}(4) * \mathrm{D}(\mathrm{GDP}(-$

$3))+\mathrm{C}(5) * \mathrm{D}(\mathrm{GDP}(-4))+\mathrm{C}(6) * \mathrm{D}(\mathrm{GDP}(-5))+\mathrm{C}(7) * \mathrm{D}(\operatorname{ELEC}(-$

$1))+\mathrm{C}(8) * \mathrm{D}(\operatorname{ELEC}(-2))+\mathrm{C}(9) * \mathrm{D}(\operatorname{ELEC}(-3))+\mathrm{C}(10) * \mathrm{D}(\operatorname{ELEC}(-$ 4) $)+\mathrm{C}(11) * \mathrm{D}(\operatorname{ELEC}(-5))+\mathrm{C}(12)$

\begin{tabular}{|c|c|c|c|c|}
\hline & Coefficient & $\begin{array}{l}\text { Standard } \\
\text { Error }\end{array}$ & t-Statistic & Probability \\
\hline $\mathrm{C}(1)$ & -1.246192 & 0.393461 & -3.167257 & 0.0074 \\
\hline $\mathrm{C}(2)$ & 0.755413 & 0.353174 & 2.138925 & 0.0520 \\
\hline $\mathrm{C}(3)$ & 1.616068 & 0.362233 & 4.461408 & 0.0006 \\
\hline $\mathrm{C}(4)$ & 1.847763 & 0.538342 & 3.432322 & 0.0045 \\
\hline $\mathrm{C}(5)$ & 1.411433 & 0.628181 & 2.246857 & 0.0427 \\
\hline $\mathrm{C}(6)$ & 0.900467 & 0.563594 & 1.597722 & 0.1341 \\
\hline $\mathrm{C}(7)$ & -1230.988 & 463.8372 & -2.653923 & 0.0199 \\
\hline $\mathrm{C}(8)$ & -1930.714 & 486.5903 & -3.967844 & 0.0016 \\
\hline $\mathrm{C}(9)$ & -1773.602 & 623.9508 & -2.842535 & 0.0139 \\
\hline $\mathrm{C}(10)$ & -733.5864 & 629.4578 & -1.165426 & 0.2648 \\
\hline $\mathrm{C}(11)$ & -210.8841 & 494.8982 & -0.426116 & 0.6770 \\
\hline $\mathrm{C}(12)$ & 355255.2 & 166143.6 & 2.138241 & 0.0521 \\
\hline \multicolumn{2}{|c|}{ R-squared 0.768404} & \multicolumn{3}{|c|}{ Mean dependant var 346849.9} \\
\hline \multicolumn{2}{|c|}{$\begin{array}{c}\text { Adjusted R-squared } \\
0.572439\end{array}$} & \multicolumn{3}{|c|}{ S.D dependant var 322271.4} \\
\hline \multicolumn{2}{|c|}{$\begin{array}{c}\text { S.E of Regression } \\
210727.4\end{array}$} & \multicolumn{3}{|c|}{ Akaike info criterion 27.66059} \\
\hline \multicolumn{2}{|c|}{$\begin{array}{c}\text { Sum squared residual } \\
5.77 \mathrm{E}+11\end{array}$} & \multicolumn{3}{|c|}{ Schwarz criterion 28.24565} \\
\hline \multirow{2}{*}{\multicolumn{2}{|c|}{ Log likelihood -333.7574 }} & \multicolumn{3}{|c|}{ Hanan-Quinn criterion 27.82286} \\
\hline & & \multicolumn{3}{|c|}{ Durbin Watson statistics 1.844484} \\
\hline
\end{tabular}

Obtained Econometric model for the GDP and Electricity consumption of the $1^{\text {st }}$ scenario are as follows.

$$
\begin{array}{r}
\Delta G D P_{t}=-1.25\left(G D P_{t-1}-738.17 \times E L E C T_{t-1}-\right. \\
628585.93)+\sum_{i=1}^{5} a_{i} \times \Delta G D P_{t-i}+\sum_{j=1}^{5} b_{j} \times \Delta E L E C T_{t-j}+ \\
E_{t}(2)
\end{array}
$$

After obtaining a mathematical equation from VECM, stability of the model should be checked. Four specific statistical tests should perform in order to check the stability of the model. Performed statistical tests and a brief description of those statistical tests are given below.

- Wald test

- Heteroscedasticity test

- Normality test

- Serial correlation LM(Lagrange Multiplier) test
Table VII illustrates the Wald test results between total electricity consumption and total real GDP. Chi-square value for the above case corresponds to 0.0001 probability. Hence the null hypothesis can be rejected at $5 \%$ interval.

TABLE VII: RESULTS OF WALD TEST Wald Test

\begin{tabular}{|l|c|c|c|}
\hline \multicolumn{3}{|c|}{ Wald Test } \\
\hline \multicolumn{1}{|c|}{ Test Statistic } & Value & df & Probability \\
\hline F-Statistic & 5.043221 & $(5,13)$ & 0.0087 \\
\hline Chi-Square & 25.21611 & 5 & 0.0001 \\
\hline Null Hypothesis : $\mathrm{C}(7)=\mathrm{C}(8)=\mathrm{C}(9)=\mathrm{C}(10)=\mathrm{C}(11)=0$ \\
\hline
\end{tabular}

TABLE VIII: RESULTS OF HETEROSCEDASTICITY TEST Heteroskedasticity Test Breusch-Pagan-Godfrey

\begin{tabular}{|c|c|c|c|}
\hline \multicolumn{4}{|c|}{ Heteroskedasticity Test Breusch-Pagan-Godfrey } \\
\hline F-Statistic & 1.616133 & Prob.F(12,12) & 0.2088 \\
\hline Obs*R-squared & 15.44391 & $\begin{array}{c}\text { Prob.Chi- } \\
\text { Square(12) }\end{array}$ & 0.2181 \\
\hline
\end{tabular}

Table VIII shows the hetheroskedasticity test that was performed for the above model. Heteroscedasticity test is used to check whether the variance of the model is a time function. Probability of Chi-square value shows more than $5 \%$ significance and this reveals that the model has homoscedasticity which is good.

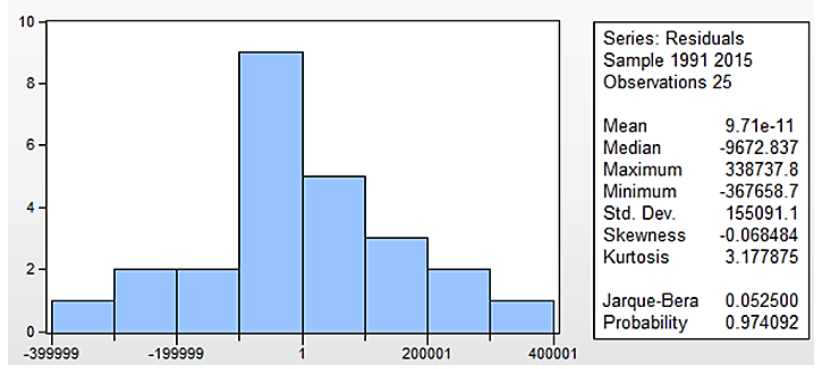

Fig. 1. Results of normality test.

Fig. 1 shows the normality test that was performed for the total Electricity consumption and total GDP. The bell shape graph can be seen in the residual series. The probability value of 0.974 reveals that it is an acceptable model.

TABLE IX: RESULTS OF SERIAL CORRELATION LM TEST Breush-Godfrey Serial Correlation LM Test

\begin{tabular}{|c|c|c|c|}
\hline \multicolumn{4}{|c|}{ Breush-Godfrey Serial Correlation LM Test } \\
\hline F-statistic & 1.837894 & Prob.F(5,8) & 0.2117 \\
\hline Obs*R-squared & 13.36497 & $\begin{array}{l}\text { Prob.Chi- } \\
\text { Square(5) }\end{array}$ & 0.0202 \\
\hline
\end{tabular}

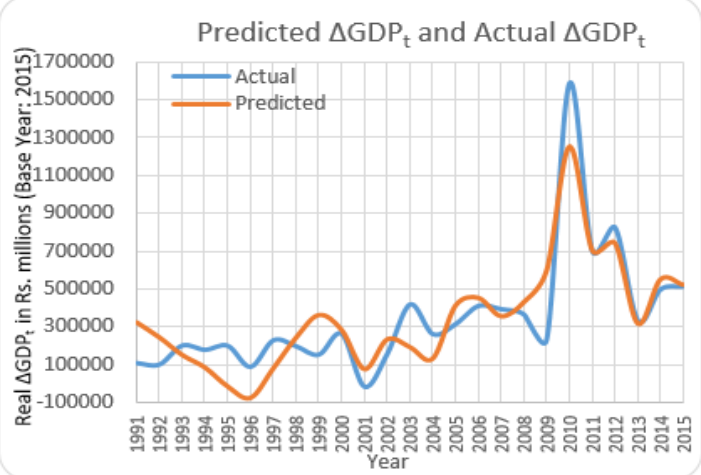

Fig. 2. Results for first scenario $\left(\mathrm{R}^{2}=0.77\right)$.

Serial correlation LM test (Table IX) is used to find the auto correlation of errors in the regression model. The test statistic was derived from use of residuals considering regression analysis. Chi-square value for the above case 
corresponds to 0.0202 probability. Hence the null hypothesis can be rejected at $5 \%$ interval.

Durbin-Watson test statistic also suggests the less autocorrelation of the residuals (Table VI). For satisfy the Durbin-Watson test, the test statistic should be in the range of 1.5 to 2.5. Obtained Durbin-Watson value for $1^{\text {st }}$ scenario is 1.84. Obtained graph for first scenario is shown in Fig. 2.

Models were developed and tested for other three scenarios as well. Results of the model outputs (Fig. 3 to Fig. 5) are shown here.

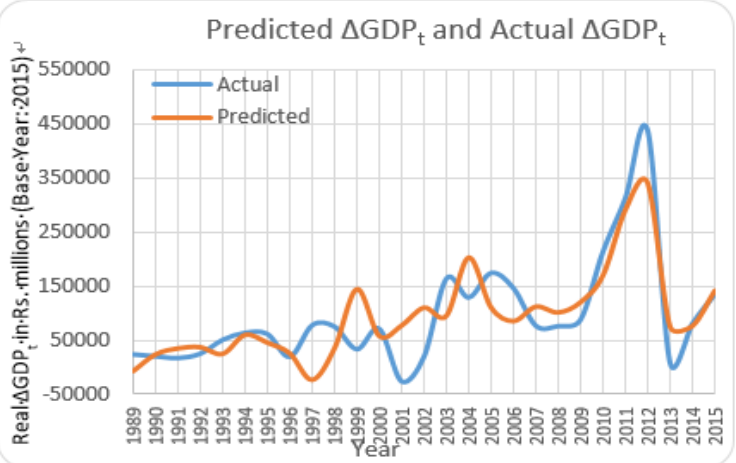

Fig. 3. Results for second scenario $\left(\mathrm{R}^{2}=0.68\right)$.

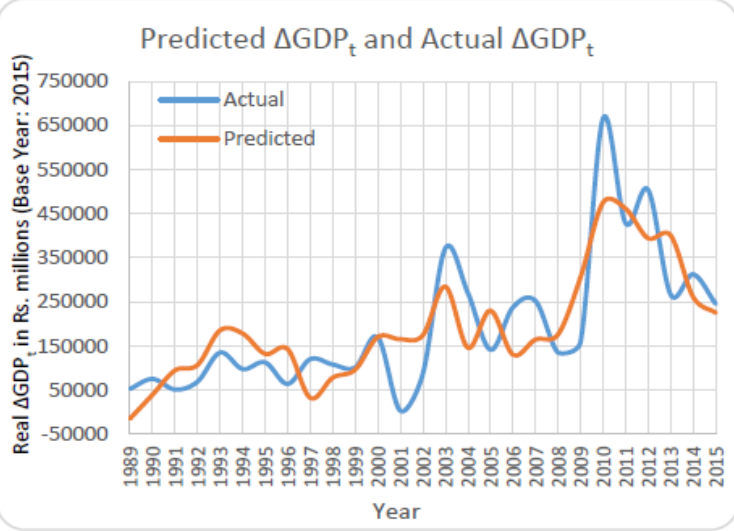

Fig. 4. Results for third scenario $\left(\mathrm{R}^{2}=0.66\right)$.

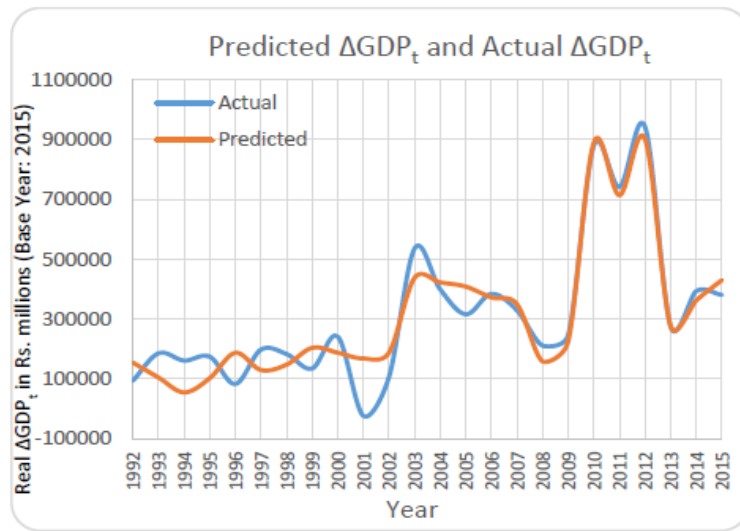

Fig. 5. Results for forth scenario $\left(\mathrm{R}^{2}=0.91\right)$.

B. Industrial Sector Electricity Consumption and Industrial Sector GDP

$$
\begin{gathered}
\Delta G D P_{t}=0.05\left(G D P_{t-1}+1744.81 \times E L E C T_{t-1}-\right. \\
5310230.37)+\sum_{i=1}^{3} a_{i} \times \Delta G D P_{t-i}+\sum_{j=1}^{3} b_{j} \times \\
\Delta E L E C T_{t-j}+E_{t}
\end{gathered}
$$

C. $3^{\text {rd }}$ Scenario: Commercial Sector Electricity Consumption and Service Sector Real GDP

$\Delta G D P_{t}=-0.84\left(G D P_{t-1}-2037.86 \times E L E C T_{t-1}+99937.98\right)+$

$$
\sum_{i=1}^{3} a_{i} \times \Delta G D P_{t-i}+\sum_{j=1}^{3} b_{j} \Delta E L E C T_{t-j}+E_{t}
$$

D. (Industrial + Commercial) Sector Electricity Consumption and (Industrial + Service) Sector GDP

$\Delta G D P_{t}=-1.2\left(G D P_{t-1}-686.68 \times E L E C T_{t-1}-1844863.37\right)+$

$\sum_{i=1}^{6} a_{i} \times \Delta G D P_{t-i}+\sum_{j=1}^{6} b_{j} \times \Delta E L E C T_{t-j}+E_{t}$

There was a difficulty to find a match for service sector GDP in electricity sector. But commercial sector electricity consumption falling under electricity sector can be considered as the most significant variable for regression analysis [14].

\section{RESUlTS AND CONCLUSION}

This paper examined the relationship between economic growth and electricity consumption in Sri Lanka for the period of 1985-2015. At first, four econometric models were developed and then the feasibility of these models were tested using statistical tests. The methodology that we have used here is Vector Error Correction Model (VECM) which falls under multiple time series models. The findings reflects that (Industrial + Commercial) sector electricity consumption and (Industrial + Service) sector GDP have a significant relationship.

According to the Johanson cointegration test performed, Sri Lanka has a Long run relationship between Electricity Consumption and Real GDP for all four cases considered.

We compared our results with another model (Simple Econometric Model) developed by H.Y. Yang (2000) [1]. Predicted ranges are approximately the same for both models.

These findings can be used to estimate the parameter EO (economic output) which indicates that the increase in economic output per increase of unit electricity consumption in Sri Lanka. Calculated extra economic outputs for every 1 GWh increase of electricity consumption for Sri Lanka are shown in Table $X$.

\begin{tabular}{|c|c|c|}
\hline \multicolumn{3}{|c|}{ TABLE X: FINDINGS } \\
\hline & $\begin{array}{c}\text { Results of from } \\
\text { Simple } \\
\text { Econometric } \\
\text { Model (Rs. } \\
\text { Mn/GWh) }\end{array}$ & $\begin{array}{c}\text { Results from } \\
\text { VECM model (Rs. } \\
\text { Mn/GWh) }\end{array}$ \\
\hline $\begin{array}{c}\text { Total GDP and } \\
\text { Electricity }\end{array}$ & 559.77 to 1156.35 & 484.61 to 1354.92 \\
\hline $\begin{array}{c}\text { Industrial GDP and } \\
\text { Electricity }\end{array}$ & 21.35 to 484.18 & 47.284 to 125.8 \\
\hline $\begin{array}{c}\text { (Industrial + Service) } \\
\text { GDP and (Industrial + } \\
\text { Service) Electricity }\end{array}$ & 687.98 to 1376.63 & 578.64 to 1068.02 \\
\hline
\end{tabular}

Some interpretations can be made on the variations of the obtained graphs. There is a huge economic growth can be seen in 2009-2010 period. This may have happened due to end of the Sri Lankan civil war from 1983 to 2009. Civil war adversely effected to the Sri Lankan economy throughout this period. 
Decline of economy in 2008-2009 period may have happened due to some undesirable situations in oil exporting countries. Sri Lankan power system was governed by oil based power plants at that time.

From 2000 to 2001, a huge decline on economic development can be seen due to energy crisis. There were some power cuts throughout the country for least 1 or 2 hours daily. Also agriculture and tourism sectors were declined in this period too.

In 1996, Sri Lanka faced a severe drought season and economy declined $3.8 \%$ from $5.5 \%$. Decrement of paddy and food crop production was happened due to this drought condition. Power cuts were also occurred because Sri Lankan power system was governed by hydro power at that time [1].

This paper confirms the significant contribution of electricity consumption to the economic development of Sri Lanka. Hence, to maintain a good economic growth, power sector should always be in a healthy condition. So that, we can say, investments in electricity sector in Sri Lanka can be fully justified, because of the significant contribution it makes to the economy.

\section{CONFLICT OF INTEREST}

The authors declare no conflict of interest.

\section{AUTHOR CONTRIBUTIONS}

All the authors conducted the research. K.K.C.S. Kiriella and W.L.T. Peiris developed the methodology and worked on literature review. K.T.A.B. Samarasinghe and W.H.A. Samarakoon analyzed the statistical data and worked on the results and conclusions. W.D.A.S Wijayapala and M.P Dias supervised the research. All authors had approved the final version.

\section{REFERENCES}

[1] C. Hope and R. Morimoto, "The impact of electricity supply on economic growth in Sri Lanka," Energy Economics, vol. 26, pp. 77 85, January 2004

[2] Z. Asghar, "Energy - GDP relationship: A causal analysis for the five countries of South Asia," Applied Econometrics and International Development, vol. 8, 2008

[3] F. Sharmin and M. R. Khan, "A causal relationship between energy consumption, energy prices and economic growth in Africa," International Journal of Energy Economics and Policy, vol. 6, pp. 477-494, no. 3, 2016.

[4] Y. Bayar and H. A. Ozel, "Electricity consumption and economic growth in emerging economies," Journal of Knowledge Management Economics and Information Technology, vol. 4, issue 2, April 2014.

[5] A. K. Tiwari, "The frequency domain causality analysis between energy consumption and income in the United States," Economia Aplicada, vol. 18, no. 1, pp. 51-67, 2014.

[6] Seec.surrey.ac.uk. Cite a Website - Cite This For Me. [Online] Available:

http://www.seec.surrey.ac.uk/Research/SEEDS/SEEDS113.pdf

[7] A. Bismark, A. Oppong, L. A. Abruquah, and E. Ashalley, "Causality nexus of electricity consumption and economic growth: An empirical evidence from Ghana," Open Journal of Business and Management, vol. 5, no. 1, January 2017.

[8] C. Aktas and Y. Veysel. Causal relationship between oil consumption and economic growth in Turkey. [Online]. Available: https://pdfs.semanticscholar.org/88e7/34f0c386dc862727b043b22dd1 f5958d0a97.pdf

[9] S. Ruhul, R. Shuddhasattwa, and K. Hassan, "Causality and dynamics of energy consumption and output: Evidence from non-OECD Asian countries," Journal of Economic Development, vol. 33, no. 2, pp. 1-26, 2008.
[10] Isiarticles.com. Cite a Website - Cite This For Me. [Online]. Available: http://isiarticles.com/bundles/Article/pre/pdf/10975.pdf

[11] S. Hossain, "Multivariate granger causality between economic growth, electricity consumption, exports and remittance for the panel of three SAARC countries," European Scientific Journal, vol. 8, no. 1, 2014

[12] S. H. Yoo, "Electricity consumption and economic growth: Evidence from Korea," Energy Policy, vol. 33, no. 12, pp 1627-1632, February 2005.

[13] B. S. Cheng, "An investigation of cointegration and causality between energy consumption and economic growth," Journal of Energy Finance \& Development, vol. 21, no. 1, December 1995.

[14] Long Term Generation Expansion Plan 2015-2034, Ceylon Electricity Board, 2015, p. 51.

Copyright $(92020$ by the authors. This is an open access article distributed under the Creative Commons Attribution License which permits unrestricted use, distribution, and reproduction in any medium, provided the original work is properly cited (CC BY 4.0).

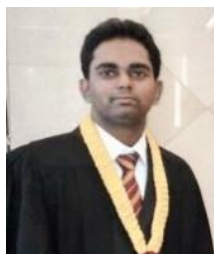

K. K. C. S Kiriella was born in Sri Lanka, on 24th April 1992. He received his B. Sc. Eng. (Hons) degree specialized in Electrical Engineering from University of Moratuwa, Sri Lanka in 2017. Currently he is reading for his MSc degree in electrical engineering in University of Moratuwa.

$\mathrm{He}$ has been working as an electrical engineer for IPD Group Ltd (Colombo branch), Sri Lanka since 2017. Eng. Kiriella is an associate member of IESL (The Institution of Engineers, Sri Lanka) since 2017

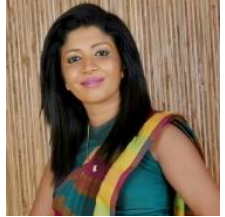

W. L. T. Peiris received the B.Sc. Eng. (Hons) degree specialized in electrical engineering from University of Moratuwa, Sri Lanka in 2017. Currently she is reading her MSc. degree in University of Moratuwa, Sri Lanka

She is now working as a lecturer (probationary) in Sabaragamuwa University of Sri Lanka since 2018 Her research interests are power systems protection, microgrids, smartgrids and power economics.

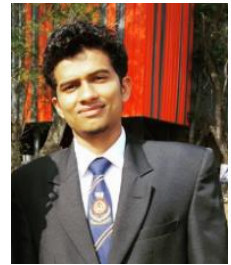

W. H. A Samarakoon was born in Sri Lanka, on 29th of November 1992. He received his B. Sc. Eng. (Hons) degree specialized in electrical engineering from University of Moratuwa, Sri Lanka in 2017.

$\mathrm{He}$ has been working as an electrical engineer for Abans Electricals PLC at Rathmalana, Sri Lanka since 2017. Eng. Samarakoon is an associate member of IESL (The Institution of Engineers, Sri Lanka) since 2017.

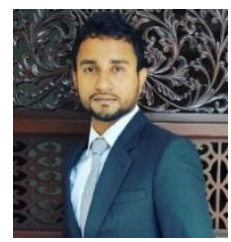

K. T. A. B. Samarasinghe was born in Sri Lanka, on 17th of June 1992. He received his B. Sc. Eng. (Hons) degree specialized in electrical engineering from University of Moratuwa, Sri Lanka in 2017. Currently he is reading for his MSc degree in electrical installation in University of Moratuwa.

He has been working as an electrical engineer for Dialog Axiata PLC, Sri Lanka since 2017. Eng. K.T.A.B. Samarasinghe is an associate member of IESL (The Institution of Engineers, Sri Lanka) since 2017.

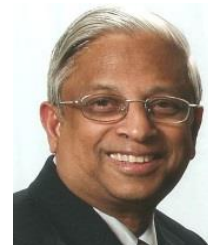

M. P. Dias, BSc Eng (Sri Lanka), MS (USA), PhD (USA) is a former associate professor of University of Moratuwa, Sri Lanka. He is also a former chairman of the Atomic Energy Authority of Sri Lanka, and a former senior staff member of the International Atomic Energy Agency. He is a recipient of the IAEA Distinguished Service Award.

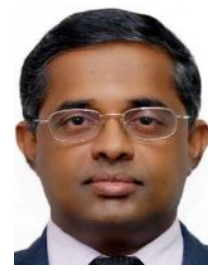

W. D. A. S Wijayapala graduated from University of Moratuwa in 1991 specializing in Electrical Engineering. He has over 25 years of experience in the electrical engineering industry in Sri Lanka. He has worked as a transformer design engineer and factory manager at Lanka Transformers Ltd, diesel power plant project engineer and plant manager at Lakdhanavi Ltd, and Manager-Hydro Power at Nividhu (Pvt) Ltd before joining the Department of Electrical Engineering of the University of Moratuwa in year 2005 as a 
Senior Lecturer (Gr1)

While serving the university, on the invitation of the Government of Sri Lanka, he has also served as Chairman of Ceylon Electricity Board, Chairman of LTL Holdings Ltd, Chairman of Sri Lanka Energies Pvt Ltd, Chairman of NERD Center of Sri Lanka, Chairman of Trincomalee Coal
Power (Pvt) Ltd, Director of Lanka Coal Company (Pvt) Ltd and Director of Lanka Electricity Company (Pvt) Ltd at different times.

$\mathrm{He}$ is a fellow of the Institution of Engineers, Sri Lanka and an International Professional Engineer. 